\title{
The potential and pitfalls of editions in educational contexts
}

\section{La posibilidad y las dificultades de las ediciones en contextos educativos}

\section{Le potentiel et les défis des éditions dans le contexte éducatif}

\author{
Rebekka Horlacher \\ Institut für Erziehungswissenschaft der Universität Zürich, Switzerland
}

\begin{abstract}
By the example of school reformer and education scholar Johann Heinrich Pestalozzi (17461827) along with editions of his writings and correspondence, this article examines the relationship between sources, research traditions, historiography, and the production of editions. What emerges is that those sources that have been turned into editions for use by researchers exercise a significant influence on the issues researchers explore and on historiography, while the kind of historiography dominant at any given moment has always privileged a particular kind of edition. In light of two examples, this paper elaborates on the problems this creates for historiography after the linguistic turn and how these can be minimized - in significant part by tapping the potential of digital editing.
\end{abstract}

Key words: historiography, Johann Heinrich Pestalozzi, editions, history of education, teacher training.

RESUMEN

Tomando como ejemplo el caso del reformador escolar y escritor sobre educación Johann Heinrich Pestalozzi (1746-1827), junto con las ediciones de sus escritos y correspondencia, este artículo examina la relación entre las fuentes, las tradiciones de investigación, la historiografía y la producción de ediciones. Lo que emerge es que aquellas fuentes que han sido convertidas en ediciones para el uso de investigadores realizan una influencia significativa sobre los temas que los investigadores explorar y sobre la historiografía, mientras que el tipo de historiografía dominante en cualquier momento dado ha privilegiado siempre un tipo particular de edición. A la luz de dos ejemplos, se estudian los problemas que esta cuestión arroja sobre la 
historiografía después del giro lingüístico y cómo estos problemas puede ser minimizados - de modo significativo aprovechando el potencias de la edición digital.

Descriptores: historiografía, Johann Heinrich Pestalozzi, ediciones, historia de la educación, formación de profesores.

\section{RÉSUMÉ}

Par l'exemple du réformateur de l'école et écrivain de l'éducation, Johann Heinrich Pestalozzi (1746-1827), et avec les éditions de ses écrits et de sa correspondance, cet article examine les relations entre les sources, les traditions de recherche, l'historiographie et la production d'éditions. Ce qui en ressort est que ces sources, qui ont été tournées en éditions à l'usage des chercheurs, et exercent une influence significative sur les questions que les chercheurs explorent et sur l'historiographie, tandis que la sorte d'historiographie dominante à aucun moment donné a toujours privilégié une sorte d'édition particulière. Â la lumière de deux exemples, cet article élabore sur les problèmes que cela pose pour l'historiographie à la suite du tournant linguistique et comment ces problèmes peuvent être minimisés en partie considérablement en exploitant le potentiel de l'édition digitale.

Mots clés: I'historiographie, Johann Heinrich Pestalozzi, les éditions, I'histoire de l'éducation, la formation des enseignants.

$\mathrm{T}$ HE SCIENCE OF EDUCATION DEVELOPED OUT OF THE DISCIPLINES of philosophy and theology in the eighteenth and nineteenth centuries and was - at least in the German-speaking world - methodologically an essentially hermeneutic science until well into the twentieth century. One of the key consequences of this 'paradigm' was a strong focus on texts as sources, and these were sought among the circles of 'major figures'; the aim here was to convey a given figure's 'spirit' or 'true character' to readers and researchers. There rapidly emerged a virtual canon of texts and authors that were regarded as relevant and were the subject of a ceaseless flow of editions. The "history of education" as a discipline was generally written on the basis of these texts, which is why educational history was - or still is - often the history of the ideas of 'major figures' who were incorporated as such into teacher training curricula. It is striking that the 'model' of the history of education developed within the German-speaking world - history as a normative guide for prospective educators, with a clearly defined canon of key figures and texts - was imitated in other countries, though with reference to figures considered relevant to each national tradition (Tröhler, 2006, p. 547). In his Essays on Educational Reformers of 1868, for example, Englishman Robert Herbert Quick complained: "I have found that on the history of Education, not only good books, but all books are in German” (Quick, 1868/1874, p. IV). The author of the first French-language history of education, meanwhile, stated that: "It was for the most part the German educational literature that provided me with the materials used to write this book" (Paroz, 1868/1869, p. 4). ${ }^{1}$

However, in addition to this history-of-ideas perspective, in the nineteenth century we also find a broad range of research in the history of schooling whose forerunners can be identified in the eighteenth century (Oelkers, 1999, p. 463). This includes not just the philanthropists who sought to collate the educational knowledge of the time and use it to enhance practical educational activities through their project of 
“General Revision” (Campe, 1785-1792), but also those individuals often referred to collectively within German-language reception history as Schulmänner or pedagogues (Tenorth, 2003). They were concerned primarily with the reform and enhancement of the education system as such - their perspective thoroughly international and comparative - and they often worked as headmasters or for an educational authority. Towards the end of the nineteenth century, this group of individuals came under pressure on two fronts. First, from the diverse educational reform movement, which had always been partly associated with a critique of the established state school system; second, from an education that was gaining ground as an academic discipline and sought to retain interpretive sovereignty over educational phenomena and, in the first third of the twentieth century, systematized progressive education (Reformpädagogik) according to its own logic (Nohl, 1935).

Research in the history of schooling was increasingly marginalized with the emergence of this humanities-based education, a term that includes a broad mix of different views that resists neat incorporation into an unambiguous research paradigm and in fact represents a "diffuse conglomerate of divergent positions - having a common denominator of politicised, histrionic, and aestheticised slogans - that transcend scientific borders to both incorporate and reinforce dominant mental dispositions and movements in society" (Tröhler, 2003, pp. 761-762). In its research, humanitiesbased education relied on the art of Verstehen or understanding, an approach developed by Wilhelm Dilthey (1833-1911) in opposition to the "explanation" provided by the natural sciences (Dilthey, 1883). Nineteenth-century research in the history of schooling was often carried out by educators and headmasters who also taught (or, in any case, by individuals close to the chalkface). This situation moved research on history of education away from the centre of academic attention. In the context of the professionalization and above all of the academization of teacher training in the second half of the nineteenth and early twentieth centuries, these actors were increasingly ousted from this field. It was impossible to integrate them into the paradigm of humanities-based education, which was increasingly gaining interpretive sovereignty, as they were interested in concrete issues in educational policy or school practice, areas that entailed few points of contact with the 'spirit' or 'idea' of the 'educational' and of the 'pedagogical.' Meanwhile, the experimental education research developed in the early twentieth century, which was geared towards the methods of the natural sciences, never managed to liberate itself from its marginal disciplinary existence and soon lost all relevance (Ritzi \& Wiegmann, 2010).

After the Second World War, however, adherence to a history-of-ideas historiography was associated with a gradual loss of importance for the history of education. This was not only because scholars began to fundamentally question the explanatory potential of history, but also because of the rise of empirical research methods that promised to generate secure knowledge - knowledge that would allow for the optimization of the "school as system." Even the social historical turn in the history of education in the 1970s only partially slowed this loss of significance. Certainly, the rise of social history opened up a broader horizon of research questions and themes, some of which had already been tackled by the nineteenth-century research in the 
history of schooling, most of them subsequently forgotten. But this shift failed to persuade people of the societal legitimacy of the history of education, which was an increasingly pressing problem despite attempts "to harness historical issues to enrich teachers' practical work" (Knoop \& Schwab, 1994, p. 12). In very general terms, the legitimacy of the discipline of history as a means of answering normative questions in education and schools was increasingly disputed. Responsibility for tackling such issues was transferred to the philosophy of education, general education, or general didactics. ${ }^{2}$ These subjects certainly expressed their arguments with reference to historical texts or figures, but rather than reading them in context, they read them as context-free normative positions used to back up a given line of argument. A historical approach had thus become dominant within the science of education that claimed to argue in a historical fashion, but that essentially sought to legitimize normative stances with reference to historical 'guarantors.'

This development and the concomitant questions about the fundamental legitimacy of an historical approach to issues in child-rearing and education led to intensive methodological debates on just how history of education might be practiced (Compère, 1995; Horlacher, 2009; McCulloch, 2011). Should history of education take its lead from the historical sciences and their methods and standards, and thus become a historical subdiscipline alongside political history, military history, or the history of art? Should history of education devote itself to the "educational or pedagogical" dimension and thus pursue a type of research found within the tradition of humanities-based education, though with modern methods and drawing on a more diverse range of sources? Or should history of education, while taking its lead from the methods and standards of the discipline of history, also generate its key foci in light of educational praxis and the associated theory building, which would also underline the discipline's autonomy (Böhm, 2004, pp. 7-9; Knoop \& Schwab, 1994 , pp. 15-16; Tenorth, 1975)? While all these possibilities were being discussed in the German-speaking context, one opportunity more common in the North American context was widely omitted: a shift away from academic discipline and towards relevant research topics. From this perspective, research in history of education would no longer be determined by the researcher's disciplinary affiliation or the institutional setting of research, but would instead depend on the choice of topic and the researcher's key concerns. With this shift, research would be dominated by the topic, research question, and relevant methods, and would less care about a more or less 'virtual' allocation of a research field along disciplinary boundaries.

To flesh out these nineteenth and twentieth-century historiographical developments and shed light on how the history of education can be and has been written, I turn now to the example of the reception and associated historiography of the person and writings of Swiss social reformer, educational commentator, and institute head Johann Heinrich Pestalozzi (1746-1827). During his lifetime, Pestalozzi established himself as probably the best-known and most influential voice within the European debate on child-rearing and education (Tröhler, 2013). He achieved this status partly through his 1781 novel Leonhard and Gertrude [Lienhard und Gertrud], a sentimentalist portrayal of a family threatened with destitution. With the support of a caring ruler, 
a virtuous mother leads not just her family but the entire village community into a bright future. Also significant were his practical activities as head of an institution that rapidly developed into a school for the new elites of the early nineteenth century, author of numerous textbooks and teaching materials and the 'inventor' of a 'method' that provided European governments with a means of educating the general population efficiently, inexpensively, and effectively (Horlacher, 2013). His work retained its prominence after his death, and over the course of the nineteenth century he attained an undisputed status as one of the most venerated sages of education and pedagogy.

Obviously, the canonization of Pestalozzi can only be understood in light of the various editions of his writings, which accompanied and powerfully reinforced this process. During his lifetime, Pestalozzi had published what ultimately amounted to a fifteen-volume edition of his collected works, ${ }^{3}$ a publishing strategy comparable to that of other major contemporary thinkers. By preparing the final edition authorized by the author himself in which he has incorporated revisions and additions, an author could help determine what people would see as his intellectual 'legacy,' and separate the important from the less important texts. Pestalozzi's stylization as a tragic, heroic, Jesus-like figure, which had already begun during his lifetime and which he himself actively supported, intensified after his death. Around twenty years later, there are references in the literature to the "genius" of "Father Pestalozzi" (Bandlin, 1846) and - to cast his reception in somewhat simplistic terms - his work was reduced to certain "key educational principles" (Propst, 1846). His oeuvre had thus completed key stages on the path towards classical status: a multilayered body of work had been reduced to a manageable stock of texts, maxims, and theoretical stances in a form that could be handed down and subjected to constant reinterpretation. This entailed the inclusion, in various popular, classical, and study editions, of short texts by Pestalozzi that were considered 'easily' readable, further bolstering his canonized reception.

It might sound like a truism: the availability of texts is crucial for the reception of the ideas, works, and thoughts of a specific historical figure. Easy, accessible texts predetermine indirectly between 'important' and 'less important' sources, and they predetermine the image of a person in the process of reception. In other words: unedited texts or archival materials are rarely used for research, particularly outside the community of 'real' historians, and they therefore contribute less to the construction of the historical figure than easy, accessible text. By investigating the case of Pestalozzi, the present article probes the connection between source, edition, research tradition, and historiography. I first trace Pestalozzi's development into a classical figure of education, a transformation that is closely bound up with the role of the "history of education" genre in teacher training. This also casts light on the close connections between editions and (dominant) research paradigm. Second, with reference to the publication of Pestalozzi's writings, I bring out the potential of so-called classics when they are discussed from novel historiographical and methodological perspectives. Third, I outline two fields of research suggested by this case study, which allows me to unearth the potential value of source editions. In the fourth and final section I outline one possible use of such editions, particularly in light of the new possibilities 
created by digital forms of publication.

\section{The history of education as a means of educators' moral instruction}

The rise and success of the "history of education" genre is closely bound up with the institutionalization and professionalization of teacher training in the nineteenth century. The geologist Karl Georg von Raumer (1783-1865), whose publications were based on lectures given in Halle in 1822 and Erlangen between 1838 and 1842, is regarded as the true "founder" of this genre. He explained his choice of this topic in light of his experience as a teacher and the necessity, as such, not only to impart knowledge but also to achieve competence in the "art of teaching" (Raumer, 1846, p. III). His key focus here was on "educational ideals" and knowledge of how a particular society in a specific era raised its children and the ways in which a given educational ideal was imparted. ${ }^{4}$ Raumer pursued this program in subsequent publications in which he portrayed the "great figures in education" of the Middle Ages and Italian Renaissance. He was forthright in his views on various issues and rejected the notion of an "objective account," since this provides no moral guidance. ${ }^{5}$ What he had in mind here was a "scientized" historiography that placed greater emphasis on the sources (and thus their critique) and that worked on the assumption that sources "speak for themselves," facilitating the greatest possible degree of historical authenticity (Berding, 1990, pp. 13-14). History was in fact no longer the kind of philosophical history characteristic of the Enlightenment, but was instead based on sources - though this did not mean abandoning claims to "utility" or "application."

Raumer supplemented the individual volumes of his History of Education [Geschichte der Pädagogik] with brief excerpts from the authors under discussion, biographical lists, institutional pamphlets, and methodological texts. Contrary to the intentions expressed in the foreword, however, he did not focus exclusively on personalities, but also devoted considerable attention to the school as an institution and the practice of teaching in its various historical manifestations. By emphasizing "major figures" in the foreword, Raumer was building on the tradition of historicism so dominant during the nineteenth century, which focussed largely on the "great ideas" of "great men" who were regarded as bringing about developments and changes (Droysen, 1857/1972). This concept was also attractive to Raumer as it enabled educators to examine and strengthen their moral ideas by grappling with their own history and with the "great educators." Methodological and institutional topics were also considered, since the history of education must not only shape educators, morally, but also provide them with guidance on the institutional and methodological-didactic setting of the school. In line with this, this history offered educators the chance to assess their practical activities and to "discuss" their own perceptions and ideas with moral authorities.

The four-volume History of Education [Geschichte der Pädagogik] (1860-1862), published a few years later by Karl Schmidt (1819-1864), took a rather different tack. Schmidt had studied theology in Halle and took up a post as grammar school teacher in Köthen in 1845. In 1863, he was appointed department head and school inspector in Gotha, where he died shortly afterwards. Schmidt took a philosophy-of-history 
approach that considered phylogenesis and ontogenesis in parallel and assumed that it is the task of history "to actualize the reason that lies within humanity and to lead people to God as its ultimate ground" (Schmidt, 1860, p. 3). In this view, then, the development of humanity is reflected in history (p. 7). For Schmidt, moreover, the development of the individual person was always bound up with the development of the people, which is why he believed that education is necessarily linked with national culture and that the history of education in fact represents a history "of progress in the idea of humanity" (p. 8). This history, with its teleological arguments, focused not on the individual personality but on the people or nation and privileged a progressive perspective, though Raumer himself was more concerned with the moral guidance of the individual.

The numerous "histories of education" of the nineteenth and twentieth centuries generally adhere to this conception. In terms of content, they cover a fairly broad spectrum extending to the late nineteenth century, generally begin with Greek and Roman antiquity, and deal, in a fair degree of detail, with the Christian Middle Ages. These histories pay particular attention to the history of the school as institution, including colleges, academies, and universities, and they usually contain a history of the development of methodology and didactics as well. A few publications here and there deal with female actors, though generally in appendices rather than pursuing the topic in its own right (Wendt, 1879). These histories were generally written by senior teachers who were dissatisfied with existing publications, whether because they were too complex, too schematic, or too biased (Largiadèr, 1883, p. 6). At other times, existing textbooks were edited down into more compact and targeted versions to enable trainee teachers to better prepare for exams (Kloepper, 1879; Schumann, 1874, 1876/1877).

Raumer and Schmidt represent the basic models of the German-speaking "history of education," a model that grew rapidly in importance after 1871, remained relatively uninfluenced by historiographical developments, and was reproduced until well into the 1970s. What I mean by basic model is an emphasis on the moral dimension and a focus on one's own "people" or "nation": the typical producers of histories of education were German (and members of Reformed or Lutheran churches) and were molded by a deep conviction that it is possible to "learn" from history (Gonon, 1999; Koinzer \& Loeffelmeier, 2009). What we find is that, with the massive increase in such publications from the 1870 s on, the question of the validity of this genre receded into the background. While Raumer was still justifying his publication with reference to his own experience as a teacher, in the foreword to the first 1877 edition of his history of education, Johann Böhm took it for granted that "nowadays there is probably no educator left who is in any doubt... about the value of the history of education, pedagogy and methodology" (Böhm, 1877/1892, p. I).

To summarize, on the cusp of the twentieth century the history of education had become a regular feature of the teacher-training curriculum. It did not see itself primarily as part of the discipline of history, but as a reservoir of histories and biographies, with Pestalozzi being one of the undisputed greats. These served as a source of moral guidance for prospective and active educators, and the primary source 
collections and text editions that appeared in parallel to them provided the history of education with a clearly defined profile. Central to historical research in education were individual figures, who were accessible through their biographies and a clearly defined textual corpus, and who were examined with a view to their significance to history and/or the contemporary era and the relations and interactions between them. This did not entail any attempt to locate the key foci of history of education within a general research context. Instead, these foci were legitimized in light of their use in the training of educators, engendering a discursive milieu largely sealed off from the influence of other disciplines or research contexts.

\section{New methodological premises}

In the twentieth century, classical editions were increasingly edited in line with scientific precepts, and Pestalozzi was an obvious candidate for such an edition (Osterwalder, 1996, p. 12). Plans were soon afoot both for an edition of his oeuvre and of his correspondence. The former was not only to include Pestalozzi's published writings, but also his extensive handwritten literary remains, with a place for everything "of value to a scholarly edition" (Buchenau, Spranger \& Stettbacher, 1927, p. VI). The volumes of correspondence was to include only letters by Pestalozzi, with the exception of his correspondence with his later wife Anna Schulthess (1738-1815) which - at least with respect to the period before their marriage - was an integral part of the first volume. Pestalozzi's correspondents, meanwhile, played an illustrative role at best. "Pestalozzi's 'collected works' are to be a monument to the great man," as editors Artur Buchenau, Eduard Spranger, and Hans Stettbacher put it in the foreword to the first volume, which appeared in 1927 (p. VIII). The original plan for the edition of correspondence was postponed in substantial part because of the outbreak of the Second World War, and the first volume appeared after a delay of almost twenty years in 1946. This did little to change the historiographical approach pursued in this publication. "The letters of Heinrich Pestalozzi constitute such a significant part of his life's work that it cannot be fully appreciated without them," wrote the two editors of the correspondence in their preface (Burckhardt \& Stettbacher, 1946, p. VII), again emphasizing the hermeneutic character of the volume: the goal was to "understand" an oeuvre or individual.

In a review twenty years later, Max Liedtke (b. 1931), a prominent educationalist and author of a biography of Pestalozzi, criticized the omission of the correspondents' letters. It would have been valuable to "print the letters of Pestalozzi's correspondents in full here and there to illuminate the factual explanations. This exception could have been made particularly in the case of the letters of Mrs Pestalozzi” (Liedtke, 1968 , p. 515). Even in this critique, however, the focus remained on the person of Pestalozzi. It was the letters that documented Pestalozzi's personal development, or in which Pestalozzi as an individual stood centre stage, that were of interest. Pestalozzi's correspondents were significant in their capacity to shed light on Pestalozzi as an individual or his convictions rather than in their own right, or in their function as actors within the comprehensive debate on reform that took place at the dawn of the nineteenth century, a debate that cannot be reduced to the person of Pestalozzi. 
Although there was initially no plan to publish them, an extensive corpus of letters to Pestalozzi had been amassed in connection with the volume of correspondence, the original idea being to use them solely to elucidate the letters by Pestalozzi. Over the course of time, this collection developed into a book series in its own right. Discussions over whether and, if so, how these letters ought to be edited led to a grave dispute with the sponsors of the first two series regarding the quality, scientific character, and significance of the Pestalozzi edition. This paralyzed the publication process for twenty years (Dejung, n.d.). Work on the edition was resumed following the death of long-standing editor Emanuel Dejung (1900-1990) in the 1990s, and was set to begin on the final volumes of Pestalozzi's oeuvre and letters. It stood to reason that the third series, the letters to Pestalozzi, should be prepared for publication as well, though after an edition history of more than sixty years, the original concept of the edition had to be revised and adapted to new editorial and historiographical considerations.

In the nineteenth and early twentieth century, the notion that history can provide moral guidance and that editions must adhere to a hermeneutic research paradigm was not peculiar to educational historiography, but applied to historiography very generally, though above all to political history. Political history was understood explicitly as providing a basis for the training of prospective civil servants and politicians, though it was increasingly superseded by subjects such as economics and law during the first half of the twentieth century. As a result of this process, the discipline of history was forced, far earlier and far more than education, to clarify its self-understanding as a science and, in connection with this, to stake out a new role. In the German-speaking world, this reorientation was closely linked with the role of leading historians during the Nazi period, a role that had reinforced the discrediting of traditional historiography. These historical entanglements encouraged scholars to look beyond their own linguistic and national boundaries.

For the educational sciences, the great challenge in the period after the Second World War was not primarily the question of how to deal with its past, but instead came from empirical psychology, whose methods allowed it to generate results that held great appeal for actors within science, education policy, and educational practice (Tröhler, 2015). This "turn towards realism in educational research" - to quote the title of the 1962 inaugural address by Heinrich Roth (1906-1983) that first identified this "turn" as such in the German-speaking countries - placed "reality" centre stage within educational research, sharpening the dividing lines within the discipline between history, empirical work, and theory. This development applied in particular to the history of education, since it understood education and pedagogy - and thus itself - as located within a philosophical tradition (Blättner, 1968, p. 5). To a great extent, history of education remained beholden to a hermeneutic and humanities-based research tradition and opened itself only very hesitantly to a social scientific or social historical approach. The methodological shifts of the 1970 s and 1980 s, which privileged an institutional or gender history approach, only very partially changed this humanities-oriented historiography with its fixation on individuals and classics. Particularly in the case of gender history, rather than questioning basic 
historiographical conceptions, taking a new approach merely meant supplementing the prevailing focus on great men with consideration of a few great women (Weimer \& Jacobi, 1992).

It was only with the linguistic turn, which mostly took the form of discursive history within German-speaking educational science, that scholars began to seriously question historiographical practices and demand new sources unavailable in the familiar classical editions. These new sources included journals, pamphlets, and leaflets, but also archival materials such as letters. The linguistic turn shifts the focus of historical research away from a history of individuals or institutions towards one focused on language, one that understands individuals and events in and in light of their cultural, social, and historical environment and reads this context itself as a text. The new plan for the edition of letters to Pestalozzi ${ }^{6}$ mirrored the historiographical concepts foregrounded by the linguistic turn (Tröhler, 1998). It was no longer individual figures who had achieved renown for whatever reason who were of particular interest, but rather correspondents and their statements and ideas as a whole, as manifest in their surviving writings. The history of the edition, however, could not be disregarded entirely. Certain practical constraints, arising from this history, clash to some degree with the theoretical precepts of the linguistic turn: if one were to be entirely consistent, it would be necessary to radically amend the person-centred framework. From this new perspective, it is no longer the verified authorship of a letter that is decisive to its inclusion in an edition - a criterion that had formerly been crucial - but rather the letter's origin in a particular institutional or intellectual context. From 1800 on - in other words, during the period when Pestalozzi was active mainly as head of an institute that was making waves across Europe - it would have been necessary to edit not just the letters from and to him, but the entire correspondence written by and to the institute staff, as well as that between staff members. While Pestalozzi was the head and figurehead of the institute, his colleagues played a crucial role in its organization and development and in the associated publishing activities.

\section{Research fields}

I elaborate on this new methodological premise - understanding text and context as suggested by the linguistic turn - by looking at two examples. The first involves the (private) school system in Switzerland that was taking hold in the early nineteenth century. There is no escaping this phenomenon when reading the letters to Pestalozzi, as many of his correspondents were active in this setting. The second example is concerned with the education policy consequences of the reordering of Europe following the Napoleonic wars. The newly established nation states found themselves confronted with the task of molding their inhabitants into 'citizens,' and, in addition to the armed forces, this task fell primarily to the school. Many of Pestalozzi's former students or colleagues played a prominent role in developing this state-organized education system. Some had been sent to Pestalozzi quite deliberately by governments to train and prepare them for this role.

Around 1800, a multitude of private schools had become established in Switzerland that survived for varying spans of time (Godenzi, 2012). They met the needs of 
parents looking to educate their children but no longer satisfied with ancien regime schools, whether because they were unable to provide their children with the kind of education they needed for a successful career in the 'modern' professions or because they offered no advanced education for girls. These private schools were often associated with a form of teacher training in which the headmaster provided courses for prospective or active teachers or teachers were trained on the job. Often, these schools were established thanks to a local initiative or an individual teacher. This is evident in the case of Protestant theologian Johann Georg Tobler (1769-1843), who headed a private institute in Basel between 1801 and 1803; he also worked for a time as a teacher under Pestalozzi in Burgdorf with the aim of enhancing his methodological and didactic knowledge. Tobler's letters to Pestalozzi demonstrate the changeable nature of public opinion with respect to these private schools and how dependent they were on public goodwill and on good reputation.

On June 24, 1801, Tobler wrote to Pestalozzi from Basel that all was well and that his endeavour had already attracted a great deal of positive interest (Sämtliche Briefe an Pestalozzi I, p. 426). He already had "twenty-eight children, and more parents are turning up every day to register theirs. If things go on like this, we should soon have forty or fifty of them." Around three weeks later, on July 11, he reported that public interest in the school had tapered off, though he was very glad about this since the visitors had greatly disrupted the regular teaching day (p. 429). On October 10, Tobler related that his school was continuing to do well, but complained about the public attention it was receiving as it was of the negative variety. He detected no genuine public interest in methods or didactics, merely a general curiosity and a certain faith in miracles (p. 461). According to Tobler, any more meaningful attempt to grapple with the school's content and objectives had been superseded by the public's craving for sensation.

Three months later, on January 27, 1802, the public perception of Pestalozzi's methods and thus of Tobler's school was no longer as unreservedly positive as it had initially been. Tobler noted that some medical doctors had claimed that "shouting," in other words spelling out loud, weakens the lungs and thus children's health (Sämtliche Briefe an Pestalozzi I, p. 482). Over the following months, there were major fluctuations in Tobler's assessment of the perception of his work and his school. In March 1802, he opined that the crisis was over (p. 503). Six months later, on October 6 , it became clear that tensions had only eased temporarily (p. 552). After another six months, on March 2, 1803, Tobler felt that he had no other option than to close his institute: "In present circumstances, staying in Basel is impossible if I wish to avoid ruining myself economically and to some extent morally. But there are only three remaining ways in which I can change the situation, namely emigration to Germany, or opening in Basel an institute for French boys who wish to learn German, merged with my current school, or joining you" (p. 575). Tobler chose the third option, relocation to Burgdorf, so that after only two years of existence, Tobler's private institute in Basel was being closed, though it had experienced a genuine boom during the short period of its existence and had even had to move to new premises as the original ones had become too small. 
Tobler's experiences, which are similar to those undergone by other correspondents, put in perspective the closure of Pestalozzi's institutes, often referred to in the literature as "Pestalozzi's failures." Competition between the various providers of education was intense and, particularly during the period of the Helvetic Republic (1799-1803), with its various coups, always partly dependent on the shifting array of political authorities. Institutions emerged before rapidly disappearing, but it is not clear from the sources what the reasons for success or failure were and it is often impossible to reconstruct what might have triggered changes in public perception. Was it specific incidents involving pupils or teachers? Was it the political activities of the headmasters or educators, which were suddenly no longer suitable? Was it shifting fashions among members of the public, who were quick to embrace a given educational establishment, but equally quick to change their minds? The organization and condition of the private school system in Basel cannot be reconstructed conclusively solely on the basis of the letters sent to Pestalozzi. But these letters do allow us to generate such research questions in the first place.

The second example relates to the Napoleonic hegemony in Europe and the question of how this hegemony or the reordering of Europe that it engendered influenced the educationalization of the multifarious social, economic, and political problems of individual states. The states established after the Congress of Vienna created constitutional, legal, and administrative structures that were largely detached from the church. Schools were made over by the state or its administrative apparatus, which, to accomplish its key task - nation building - investigated secular conceptions of education without calling into question the sacredness of education itself (Hofmann, Jacottet, \& Osterwalder, 2006). The reordering of Europe initiated and expedited by Napoleon, then, was not only a matter of territorial reallocation. It also accelerated the generation of competing educational concepts, concepts focused on the new nations that must now be created, in other words on integrating all social classes into the nation state (Horlacher, 2012; Schreiber \& Geisler, 2011; Tosato-Rigo, 2012). From Spain to the czarist capital of St. Petersburg, from France to the Balkans, these concepts were compared, modified, adapted, and reworked in contradistinction to one another. The concepts that took hold, that were implemented and thus culturally assimilated, initiated the Europe-wide standardization of educational discourse, but were at the same time shaped by burgeoning national ideologies - so there was considerable variation in the complexion of the new educational orders that arose. Responsible for these new orders was a revamped state administration that was now tasked with the administration of schools. Administrative officials, journalists, educators, clergy, and politically active businessmen were the main actors in this educational market, and they adapted to the rapidly changing political currents and circumstances, offered their services and ideas to the new rulers, and thus ensured the emergence of various, contradictory, and unintended nationalist reformulations of educational agendas.

One concept that enjoyed particular success among the agents of reform was the Bell-Lancaster method or monitorial system (Caruso, 2010; Ressler, 2010), another Pestalozzi "method" that found supporters at the Spanish Court in Madrid, some 
French regions, many of the small princely states struggling for survival following the collapse of the Holy Roman Empire, Prussian Berlin, the Netherlands, and as far afield as the Baltic states and regions (Tröhler, 2002). Debates on the character and organization of the modern public school and the associated teacher training took place in newspapers, pamphlets, and other publications, but the discussions that led to the stances expressed in them can only be reconstructed via handwritten sources, mainly letters. Because Pestalozzi had become one of the venerated "sages" of the discipline at a very early stage and writings by him or those close to him therefore possessed a particular collectors' value, an extensive bundle of letters has been preserved from among the circles of Pestalozzi's colleagues, very little of which has so far been exploited; they would cast much light on the above developments. These are not just letters sent directly to Pestalozzi by former staff and pupils, but above all the correspondence that passed between these individuals. These letters thus make up a textual corpus that takes recent historiographical developments seriously, and that offers material for the writing of history according to the associated theoretical and methodological considerations.

\section{Conclusion, or: What makes for a meaningful edition?}

From a context-oriented research perspective, an edition focused on one individual, as the example of the Pestalozzi edition has shown, constrains and distorts the source material. It works on the assumption that each individual constitutes a universe of thoughts, ideas, and actions in his or her own right, one that can be separated from its context with a greater or lesser degree of clarity. This assumption is an invalid one, particularly for the period around 1800, both from a theoretical perspective and for practical reasons. At the time, letters were not only, let alone exclusively, personal messages. They were generally conveyers of information addressed not just to an individual, even when an individual was mentioned and addressed explicitly, because it was normal to circulate letters among one's friends and acquaintances. Letters must, therefore, always be read partly as general sources of information on novel developments, sources that extend beyond the description of individuals' state of mind. To remain with the example of Pestalozzi, this means that from a research-oriented perspective, it does not necessarily matter much whether a letter was addressed to Pestalozzi himself, to one of his colleagues, or to a member of his family. Conversely, neither is it decisive whether Pestalozzi wrote a letter himself, merely signed it, or took no particular position on it at all - distinctions that have been key criteria in the production of editions hitherto and that reflect a research tradition geared towards individuals and their ideas.

A focus on an individual person is problematic for theoretical reasons because it involves highlighting, in a more or less arbitrary way, persons whose importance is left unjustified both empirically and historically. The classical writer is important because of his classical status. Publications geared towards administrative structures, institutions, or specific events do direct our attention away from the individual as author and creator of ideas, developments, or changes, but they are unable to fundamentally resolve the methodological problem with which the linguistic turn has 
confronted researchers. An edition, however it is structured, cannot fully do justice to the methodological paradigm after the linguistic turn, which demands that contexts too must be understood as texts. But editions may support research informed by the linguistic turn by making contexts available as sources in the first place - and thus providing us with the source basis so vital to context-oriented research. This not only requires the liberation of editions from a philological fixation on authorship, but also demands that the corpus of sources be increasingly organized in light of research questions, though without pre-empting the research itself.

Particularly for this broad understanding of the edition, which is no longer geared towards an individual or institution, there is much to be gained from digital forms of publication. Digital editions of correspondence, for example, which are not only available online but also make recourse to shared authority control and that adhere to uniform standards, provide opportunities for networking - in a way that makes sources available beyond a given research tradition or context and thus fosters their broad-based exploitation. This goes some way to mitigating the disciplinary and historiographical fragmentation resulting from the sciences' disciplinary division. Individuals, institutions, and various forms of space will no doubt continue to be key organizational criteria for research into the future, but digital source publications in the virtual realm can be linked and networked more simply beyond these familiar ordering criteria. To operate within this field of tension, to both provide a service for researchers while also generating research questions, seems to me not only a meaningful but also an exciting task for an edition to fulfill - both within education and beyond.

\section{Notes}

1. "Les matériaux qui m’ont servi dans la composition de cet ouvrage, m'ont été fournis en grande partie par la littérature pédagogique allemande.”

2. The German-speaking academic tradition makes a close connection between topics and (sub-)disciplines. What in the English language is referred to very generally as the philosophy of education, is divided into a number of subdisciplines of educational science in the German-speaking context, subdisciplines that cultivate their own particular reference authors and topics. While German-speaking philosophy of education is broadly comparable to its English equivalent in terms of methods and theoretical framework, the two subdisciplines of general education (Allgemeine Pädagogik) and general didactics (Allgemeine Didaktik) are constructs specific to the German-speaking world. General education is concerned with theory, history, and normative-ethical issues, with a traditional proclivity for a systematic perspective that distinguishes it from a (purely) historical approach. General didactics, meanwhile, is concerned with overarching, non-subject-specific issues of didactics, which it traditionally derives from an "educational goal" that includes normative issues.

3. In 1817, Pestalozzi published an appeal for sponsors to fund the publication 
of his writings. In it he announced a plan for a twelve-volume edition with the goal "of attaining a state of peace and contentment in my later years, which is the only thing that will enable me to dedicate the time remaining to me to the ultimate purpose of my life [ensuring a sound financial basis for his institute] with a reasonable hope of success" (Pestalozzi, 1975, p. 41). The complete edition was to consist of three parts (novels, philosophical and political writings, methodological and educational writings), to be published by the renowned Cotta Verlag in Stuttgart. The first volume appeared in 1819 after some delay, while the final three volumes of what had, by then, become an edition of fifteen volumes appeared in 1826 .

4. In 1817, the appeal for sponsors had attracted a great deal of support, but the long editing period prompted many to distance themselves from their original agreement. Many of the subscribers complained the associated ambiguities, but related them not just to Pestalozzi but at least as much to the Cotta publishing house (Caluori, Horlacher \& Tröhler, 2012). "In outstanding men we find that educational ideal as if in personified form. They thus exercise the greatest influence on education, even if they are not educators. A great example inspires emulation and enriches our opinions with higher laws" (Raumer, 1846, p. IV).

5. "I openly express my opinions partly in order to stimulate readers to discuss certain important educational subjects, which a mere account of the facts generally fails to do. As this history portrays the ideals and methods of such a broad range of educators, it compels practical educators in particular to make a comparison with their own views and approach" (Raumer, 1846, p. V).

6. The letters have been edited in six volumes since 2009 (Sämtliche Briefe an Pestalozzi, I-VI).

7. The edition of letters and texts of Intellectual Berlin Around 1800, for example (http://tei.ibi.hu-berlin.de/berliner-intellektuelle/?en), may well represent the beginning of a more cooperative and more linked work in editing, as the edited writers are not chosen according to disciplinary boundaries, even though it has to be noted that the topic - intellectuals in Berlin around 1800 - is a rather common organizational paradigm in the history of European philosophy.

\section{References}

Bandlin, J. B. (1846). Der Genius von Vater Pestalozzi. Zurich, Switzerland: Höhr. Berding, H. (1990). Leopold von Ranke. In H. Berding, Aufklären durch Geschichte. Ausgewählte Aufsätz̨e (pp. 13-31). Göttingen, Germany: Vandenhoeck \& Ruprecht.

Blättner, F. (1968). Vorwort zur dreizehnten Auflage. In F. Blättner (Ed.), Geschichte der Pädagogik. Heidelberg, Germany: Quelle \& Meyer.

Böhm, J. (1892). Geschichte der Pädagogik mit Charakterbildern hervorragender Pädagogen und Zeiten (1877). Nuremburg, Germany: F. Korn.

Böhm, W. (2004). Geschichte der Pädagogik. Von Platon bis zur Gegenwart. Munich, Germany: C. H. Beck. 
Buchenau, A., Spranger, E., \& Stettbacher, H. (1827). Vorwort zu der Gesamtausgabe. In J. H. Pestalozzi, Sämtliche Werke, Kritische Ausgabe, Vol. 1 (pp. V-VIII). Berlin, Germany: De Gruyter.

Burckhardt, F., \& Stettbacher, H. (1946). Zum Geleit. In J. H. Pestalozzi, Sämtliche Briefe, Vol. 1 (p. VII). Zurich, Switzerland: Orell Füssli.

Caluori, B., Horlacher, R., \& Tröhler, D. (2012). Publizieren als Netzwerkstrategie. Zeitschrift fïr Pädagogik, 58, 877-897.

Campe, J. H. (1785-1792). Allgemeine Revision des gesammten Schul-und Erziebungswesens von einer Gesellschaft praktischer Erzieher (16 vols). Hamburg, Germany: Bohn.

Caruso, M. (2010). Geist oder Mechanik. Unterrichtsordnungen als kulturelle Konstruktionen in Preussen, Dänemark, (Scbleswig-Holstein) und Spanien 1800-1870. Frankfurt, Germany: Peter Lang.

Compère, M.-M. (1995). L'histoire de l'éducation en Europe. Essai comparatif sur la façon dont elle s'écrit. Bern, Switzerland, and Paris, France: Lang/INRP.

Dejung, E. (n. d.). Werk- und Briefausgabe Korrespondenz ED - Dr. E. Dejung - Verlag Orell Füssli / Div. Interventionen (Ordner Nr. 162). In Forschungsbibliothek Pestalozzianum Zürich, Archiv Wyman.

Dilthey, W. (1883). Einleitung in die Geisteswissenschaften. Versuch einer Grundlegung für das Studium der Gesellschaft und ihrer Geschichte. Leipzig, Germany: Duncker \& Humblot.

Droysen, J. G. (1972). Ungedruckte Materialien zur 'Historik.' Aus der Vorlesung über 'Enzyklopädie und Methodologie der Geschichte' von 1857. In J. G. Droysen, Texte zur Geschichtstheorie (pp. 11-39). Göttingen, Germany: Vandenhoeck \& Ruprecht.

Godenzi, L. (2012). Das Zürcher Privatschulwesen (1800-1820). Bildungsgeschichte. International Journal for the Historiography of Education, 2, 176-192.

Gonon, P. (1999). Historiographie als Erziehung. Zur Konstitution der pädagogischen Geschichtsschreibung im 19. Jahrhundert. Zeitschrift für Pädagogik, 45, 521-530.

Hofmann, M., Jacottet, D., \& Osterwalder, F. (Eds.). (2006). Pädagogische Modernisierung. Säkularität und Sakralität in der modernen Pädagogik. Bern, Switzerland: Haupt.

Horlacher, R. (2009). Historische Methoden. In S. Andresen, R. Casale, T. Gabriel, R. Horlacher, S. Larcher Klee, \& J. Oelkers (Eds.), Handwörterbuch Eržiehungswissenschaft (pp. 410-423). Weinheim, Germany: Beltz.

Horlacher, R. (2012). Schule als Ort politischer Bildung. In C. Aubry, M. Geiss, V. Magyar, \& D. Miller (Eds.), Positionierungen. Zum Verbältnis von Wissenschaft, Pädagogik und Politik (pp. 253-267). Weinheim, Germany: Beltz.

Horlacher, R. (2013). Do educational models impose standardization? Reading Pestalozzi historically. In T. S. Popkewitz (Ed.), Retbinking the history of education: Transnational perspectives on its questions, methods, and knowledge (pp. 135-156). New York, NY: Palgrave Macmillan.

Kloepper, K. (1879). Repetitorium der Geschichte der Pädagogik von den ältesten Zeiten bis auf die Gegenwart. Rostock, Germany: Werthers.

Koinzer, T., \& Loeffelmeier, R. (Eds.). (2009). Aus der (Bildungs-)Geschichte lernen!? Gerhard Kluchert zum 60. Geburtstag. Zeitschrift für pädagogische Historiographie, 15, 68-88.

Knoop, K., \& Schwab, M. (1994). Einführung in die Geschichte der Pädagogik (1980). Heidelberg, 
Germany: Quelle \& Meyer.

Largiadèr, A. P. (1883). Bilder zur Geschichte der Erziehung und des Unterrichts. Mit besonderer Berücksichtigung der Geschichte der Volksschule. Zurich, Switzerland, and Strasburg, France. Liedtke, M. (1968). Rezension von: Johann Heinrich Pestalozzi: Sämtliche Briefe, Vol. IX. Zeitscbrift für Pädagogik, 14, 513-515.

McCulloch, G. (2011). The struggle for the bistory of education. London, England, and New York, NY: Routledge.

Nohl, H. (1935). Die pädagogische Bewegung und ibre Theorie. Frankfurt, Germany: Schulte-Bulmke.

Oelkers, J. (1999). Die Geschichte der Pädagogik und ihre Probleme. Zeitschrift für Pädagogik, 45, 461-483.

Osterwalder, F. (1996). Pestalozzi - ein pädagogischer Kult. Weinheim, Germany: Beltz.

Paroz, J. (1868). Histoire universelle de la pédagogie. Paris, France: C. Delagrave.

Pestalozzi, J. H. (1975). Pestalozzi an’s Publikum. Iferten, im Monat März 1817. In J. H. Pestalozzi, Sämtliche Werke, Kritische Ausgabe, Vol. 25 (pp. 39-45). Zurich, Switzerland: Orell Füssli.

Propst, J. (1846). Die wichtigeren pädagogischen Grundsätz̧e von Heinrich Pestalozæi. Liestal, Switzerland: W. Honegger.

Quick, R. H. (1874). Essays on educational reformers (1868). Cincinnati, OH: Robert Clarke \& Co.

Raumer, K. von (1847). Geschichte der Pädagogik, Vol. 2. Stuttgart, Germany: Liesching.

Ressler, P. (2010). Nonprofit-Marketing im Schulbereich. Britische Schulgesellschaften und der Erfolg des Bell-Lancaster-Systems der Unterrichtsorganisation im 19. Jabrbundert. Frankfurt, Germany: Peter Lang.

Ritzi, C., \& Wiegmann, U. (Eds.). (2010). Beobacbten - Messen - Experimentieren. Beiträge zur Geschichte der empirischen Pädagogik/Erziehungswissenschaft. Bad Heilbrunn, Germany: Klinkhardt.

Sämtliche Briefe an Pestalozzi, 6 vols. (2009-2015). Edited by R. Horlacher \& D. Tröhler. Zurich, Switzerland: NZZ.

Schmidt, K. (1860). Die Geschichte der Pädagogik in weltgeschichtlicher Entwicklung und im organischen Zusammenhange mit dem Culturleben der Völker. Vol. 1: Die Geschichte der Pädagogik in der vorchristlichen Zeit. Cöthen, Germany: Paul Schettler.

Schreiber, C., \& Geisler, N. (2011). 'Un lieu protégé’? Staatsbürgerliche Erziehung im Luxemburger Schulsystem im 19. und 20. Jahrhundert. Vierteljahrsschrift für wissenschaftliche Pädagogike, 87, 439-456.

Schumann, J. C. G. (1874). Lehrbuch der Pädagogik. Hannover, Germany: Carl Meyer.

Schumann, J. C. G. (1876/1877). Leiffaden der Pädagogike für den Unterricht in Lebrerbildungsanstalten, 2 vols. Hannover, Germany: Carl Meyer.

Tenorth, H.-E. (1975). Historische Forschung in der Erziehungswissenschaft und Historischsystematische Pädagogik. In W. Böhm \& J. Schriewer, Geschichte der Pädagogik und systematische Er:iehungswissenschaft (pp. 135-156). Stuttgart, Germany: Klett-Cotta.

Tenorth, H.-E. (2003). Schulmänner, Volkslehrer und Unterrichtsbeamte: Friedrich Adolph Wilhelm Diesterweg, Friedrich Wilhelm Dörpfeld, Friedrich Dittes. In H.-E. Tenorth (Ed.), Klassiker der Pädagogik. Vol. 1: Von Erasmus bis Helene Lange (pp. 224-245). 
Munich, Germany: Beck.

Tosato-Rigo, D. (2012). Political catechisms and nation-state building in revolutionary Switzerland (around 1800). Bildungsgeschichte: International Journal for the Historiography of Education, 2, 162-175.

Tröhler, D. (1998). Pestalozzi im Spiegel seiner Korrespondenzen - Reflexionen zum ersten Band der Briefe an Pestalozzi. Paedagogica Historica, 34, 93-110. http://dx.doi. org/10.1080/0030923980340104

Tröhler, D. (2002). 'Methode' um 1800: Ein Zauberwort als kulturelles Phänomen und die Rolle Pestalozzis. In D. Tröhler, S. Zurbuchen, \& J. Oelkers (Eds.), Der historische Kontext zu Pestalozzis 'Methode.' Konzepte und Erwartungen im 18. Jahrbundert (pp. 9-30). Bern, Switzerland: Haupt.

Tröhler, D. (2003). The Discourse of German Geisteswissenschaftliche Pädagogik A Contextual Reconstruction. Paedagogica Historica, 39, 759-778. http://dx.doi. org/10.1080/0030923032000128890

Tröhler, D. (2006). Lehrerbildung, Nation und pädagogische Historiographie. Die 'Geschichten der Pädagogik' in Frankreich und Deutschland nach 1871. Zeitschrift für Pädagogik, 52, 540-554.

Tröhler, D. (2013). Pestalozzi and the educationalization of the world. Basingstoke, England: Palgrave. http://dx.doi.org/10.1057/9781137346858

Tröhler, D. (2015, forthcoming). The medicalization of current educational research and its effects on education policy and school reforms. Discourse: Studies in the Cultural Politics of Education, 36.

Weimer, H., \& Jacobi, J. (1992). Geschichte der Pädagogik. 19., völlig neu bearbeitete Auflage. Berlin, Germany: de Gruyter.

Wendt, F. M. (1879). Repetitorium zur Geschicbte der Pädagogik. Vienna, Austria: Graeser. 